\title{
Effect of Alkali Metal Compounds on Limestone Calcination in Desulfurization Process: Molecular Dynamics Simulations
}

\author{
Takahiro MURAKAMI, Noriyuki KURITA* and Ichiro NARUSE** \\ Ishikawajima-Harima Heavy Industries Co., Ltd., 1, Shin-nakahara-cho, Isogo-ku, Yokohama-shi 235-8501 \\ *Toyohashi University of Technology, Department of Knowledge-based Information Engineering, Tempaku-cho, Toyohashi-shi 441-8580 \\ ** Toyohashi University of Technology, Department of Ecological Engineering, Tempaku-cho, Toyohashi-shi 441-8580
}

\author{
脱硫プロセスにおける石灰石焼成のアルカリ金属化合物の効果 : \\ 分子動力学シミュレーション \\ 村上高広 · 栗田典之* ·成瀬一郎** \\ 石川島播磨重工業(株)，235-8501 横浜市磯子区新中原町 1 \\ *豊橋技術科学大学知識情報工学系, 441-8580 愛知県豊橋市天伯町雲雀ヶ丘 1-1 \\ **豊橋技術科学大学エコロジー工学系，441-8580 愛知県豊橋市天伯町雲雀ヶ丘 1-1
}

\begin{abstract}
In this study, the change in the desulfurization characteristics of limestone induced by adding some alkali metal compounds and chlorides to limestone was investigated by thermobalance experiments. In addition, molecular dynamics (MD) simulations were performed to elucidate the effect of alkali-metal chloride additions on the $\mathrm{CaO}$ calcination for the desulfurization process. The experimental results obtained show that the addition of $\mathrm{NaCl}$ into the limestone is the most effective in improving the desulfurization efficiency. The $\mathrm{X}$-ray diffraction analyses of the calcined seashell, limestone and $\mathrm{NaCl}-$ doped limestone found that the calcined seashell, as well as the calcined $\mathrm{NaCl}$-doped limestone, have a similar structure as the $\mathrm{CaO}$ crystal. These two materials also show a high desulfurization efficiency. The $\mathrm{MD}$ simulations show that $\mathrm{NaCl}$ doping into the $\mathrm{CaO}$ contributes to the crystallization of $\mathrm{CaO}$, while $\mathrm{KCl}$ and $\mathrm{LiCl}$ dopings have a small contribution. Therefore, the $\mathrm{NaCl}$ doping has a predominant effect on the $\mathrm{CaO}$ crystallization leading to a high desulfurization efficiency.
\end{abstract}

[Received January 12, 2006; Accepted July 20, 2006]

Key-words : Desulfurization, Calcination, Limestone, Alkali metal compounds, Molecular dynamics simulation, Sodium chloride, Calcium oxide, Seashell

\section{Introduction}

Recently, acid rain has been recognized as one of the most serious global environmental problems. Sulfur oxides $\left(\mathrm{SO}_{x}\right)$ are one of the main sources of acid rain. In a bubbling and circulating fluidized bed coal combustors, limestone is directly supplied into the combustors as a desulfurizer in order to decrease the emissions of $\mathrm{SO}_{x}$ from coal. Those combustors are operated at temperatures ranging from 1073 to $1173 \mathrm{~K}$. The limestone is calcined and sulfurized optimally under this temperature condition. In practical boilers however, limestone, which mainly consists of $\mathrm{CaCO}_{3}$, is fed excessively to improve the contact efficiency between the $\mathrm{CaO}$ produced and the $\mathrm{SO}_{2}$ emitted. When accomplishing more than $90 \%$ of the desulfurization efficiency, or burning coal with a sulfur content of more than 1 mass $\%$, it is necessary to add limestone more than four times as much as $\mathrm{Ca}$ to $\mathrm{S}$ mole ratio. Otherwise, the particle size of the limestone should be fine. ${ }^{1), 2)}$ This is because pores inside the $\mathrm{CaO}$ particles ought to be plugged as a result of $\mathrm{CaSO}_{4}$ formation. ${ }^{3)}$ As the main component of the limestone is $\mathrm{CaCO}_{3}$, which is similar to that of seashells, it is possible to use wasted seashells as a desulfurizer. In this case, the $\mathrm{CO}_{2}$ produced during the calcination of the seashells is fixed again to the seashells and recycled naturally. Naruse et al., ${ }^{4)}$ reported that the desulfurization efficiency of the seashells was over twice as high as that of the limestone. This suggests that the seashells could be used as an effective desulfurizer. To explain the mechanisms and reasons for the high desulfurization efficiency of the seashells, the chemical compositions and the mean pore size of the seashell and the limestone were analyzed. As a result, the seashell was found to contain more sodium, potassium and chlorine than the limestone. The mean pore size of calcined seashell is over six times as large as that of calcined limestone. ${ }^{5)}$ Other researchers have also studied the effect of $\mathrm{NaCl}$ on the desulfurization characteristics. They qualitatively suggested that the $\mathrm{NaCl}$-doped limestone could enhance the desulfurization efficiency. ${ }^{6}{ }^{-9}$ ) However, the reason of the high desulfurization efficiency of $\mathrm{NaCl}$-doped seashell has not always been explained at an atomic level yet.

This study evaluates the change in the desulfurization characteristics of limestone induced by the addition of some alkali metal compounds and chlorides, by using a thermobalance experiment. The crystal structures of calcined seashell, limestone and $\mathrm{NaCl}$-doped limestone are also analyzed using an X-ray diffraction (XRD) analyzer. Furthermore, the molecular dynamics (MD) simulations are performed for both the pure $\mathrm{CaO}$ and $\mathrm{NaCl}$-doped $\mathrm{CaO}$ to elucidate the effect of the addition of $\mathrm{NaCl}$ on the $\mathrm{CaO}$ calcination process. The MD results obtained are discussed in terms of electrostatic interaction energies between $\mathrm{Ca}-\mathrm{O}$, $\mathrm{Na}-\mathrm{O}, \mathrm{Ca}-\mathrm{Cl}$ and $\mathrm{Na}-\mathrm{Cl}$. The effect of other alkali metal chlorides $(\mathrm{KCl}$ and $\mathrm{LiCl})$ on the $\mathrm{CaO}$ crystallization is also examined and compared with the results for the $\mathrm{NaCl}$-doped $\mathrm{CaO}$. Finally, the MD results obtained are compared with the desulfurization result.

\section{Experimental and simulation method}

2.1 Experimental method

In the desulfurization experiments, a thermobalance experiment was used with samples of scallop and Tsukumi limestone 
Table 1. Conditions of Molecular Dynamics Simulations

\begin{tabular}{cccc}
\hline Number of atoms & \multicolumn{3}{c}{$864(\mathrm{Ca})$ and $864(\mathrm{O})$} \\
\hline Temperature pattern $[\mathrm{K}]$ & 298 & $6900-7100$ & 298 \\
\hline Simulation time [ps] & 10 & 10 & 10 \\
\hline Pressure [MPa] & \multicolumn{3}{c}{0.1} \\
\hline $\begin{array}{c}\text { Parameters in } \\
\text { potential functions }\end{array}$ & Kawamura model \\
\hline Charge of atoms & $\mathrm{Ca}=2.0, \mathrm{O}=-2.0$ \\
\cline { 2 - 3 } & $\mathrm{Na}, \mathrm{K}, \mathrm{Li}=1.0, \mathrm{Cl}=-1.0$ \\
\hline
\end{tabular}

of particle diameters ranging from 297 to $420 \mu \mathrm{m}$. The calcination and desulfurization of the samples were carried out at $1123 \mathrm{~K}$, which is similar to the operating condition of the fluidized bed combustion. A small amount of alkali metal compound powders were physically mixed with the limestone particles. Agents of chlorides, carbonates and hydroxides were individually added to it in amounts ranging from 0.5 to 3.0 mass $\%$.

\subsection{Simulation method}

In the MD simulation, the program package WinMASPHYC Pro1.0 was used. ${ }^{10)}$ The potential parameters developed by Kawamura ${ }^{10), 11)}$ were adopted in this simulation. The conditions of the MD simulations are shown in Table 1. First, a cubic cell composed of 864 molecules of the $\mathrm{CaO}$ is made as a unit cell, in which the structure of $\mathrm{CaO}$ is constructed, based on the NaCl-like crystal structure. ${ }^{12)}$ This unit cell is periodically arranged three-dimensionally to construct the $\mathrm{CaO}$ crystal structure. The MD simulations are carried out under the condition of a constant number of atoms and pressure. The initial calculation temperature is set to be $298 \mathrm{~K}$ to obtain the crystal structure of $\mathrm{CaO}$. Then, the temperature is changed to from 6900 to $7100 \mathrm{~K}$. Finally, the temperature is reduced to $298 \mathrm{~K}$ in order to anneal the $\mathrm{CaO}$ structure. It is noted that the MD simulation temperature does not correspond to the actual temperature of calcination, because the temperature based on Kawamura's potential parameters is much higher than the actual temperature. Therefore, the temperature condition of the simulation is given as the decomposed temperature of the crystal structure after the temperature increases rapidly. ${ }^{11), 13)}$ The simulation time at each temperature is about $10 \mathrm{ps}$, and the time step of simulation is 30 ps. In order to discuss the effect of the $\mathrm{NaCl}$ doping into $\mathrm{CaO}$, one molecule of $\mathrm{CaO}$ in the initial $\mathrm{CaO}$ crystal structure is substituted by one molecule of $\mathrm{NaCl}$. The MD simulations for the substituted compound are also carried out under the same MD conditions as those for the pure $\mathrm{CaO}$.

The interaction energy between the atoms is modeled by the potential energy parameters developed by Kawamura. ${ }^{10), 11)}$ The energy $(E)$ between the $i$ th and the $j$ th atom is described as

$$
E=\frac{Z_{i} Z_{j} e^{2}}{r_{i j}}+A_{i j} \exp \left(-B_{i j} r_{i j}\right)-\frac{C_{i j}}{r_{i j}{ }^{6}}-\frac{D_{i j}}{r_{i j}{ }^{8}}
$$

In this equation, the first term in the right hand side represents the Coulomb interaction, the second indicates the repulsion interaction, and the third and fourth terms indicate the van der Waals interaction between the atoms. Here, $Z_{i}$ and $Z_{j}$ stand for the charges of the $i$ th and the $j$ th atom, respectively. The distance between the $i$ th and the $j$ th atom is represented by $r_{i j}$, while $A_{i j}, B_{i j}, C_{i j}$ and $D_{i j}$ indicates the potential parameters between the $i$ th and the $j$ th atom. ${ }^{10)}$ As the main purpose in this study is to elucidate the effect of $\mathrm{NaCl}$ doping into the $\mathrm{CaO}$ on the crystal structure qualitatively, Kawamura's model is adopted for the MD simulation. Although the compressibility of ionic crystal evaluated by this model is relatively smaller, compared to the experimental

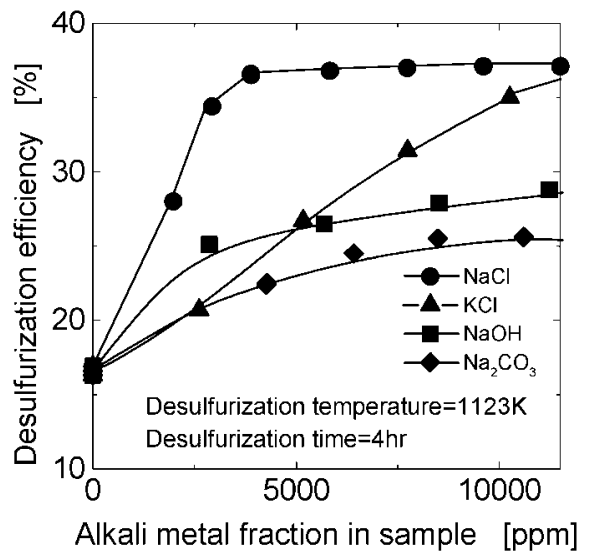

Fig. 1. Effect of the addition of alkali metal compounds and chlorides into the Tsukumi limestone on the desulfurization efficiency.

one, ${ }^{10), 11)}$ the simulated lattice constant agrees well with the theoretical value. The results obtained are discussed in terms of the change of potential energy induced by the $\mathrm{NaCl}$ substitution. Additionally, the effects of $\mathrm{KCl}$ and $\mathrm{LiCl}$ substitutions are also studied under the same MD conditions.

\section{Results and discussion}

3.1 Effect of doping of alkali metal compounds into limestone on desulfurization characteristics

In order to study the effect of the presence of some alkali metal compounds in the limestone on the desulfurization characteristics, some traces of chlorides, carbonates and hydroxides are added into the limestone. The desulfurization experiments for each sample are conducted using a thermobalance. Figure 1 shows the relationship between the desulfurization efficiency and alkali metal fraction added to the Tsukumi limestone. The results show that the desulfurization efficiency enhances for all of those additives. The addition of $\mathrm{NaCl}$ into the limestone is the most effective agent on improving the desulfurization efficiency. The desulfurization efficiency for the limestone with 1 mass $\%$ of $\mathrm{NaCl}$ was almost the same as that for the wasted seashell. ${ }^{4), 5)}$ The mean pore size of about $0.39 \mu \mathrm{m}$ for the $\mathrm{NaCl}$-doped limestone after calcination was found to be comparable to that for the calcined seashell, but for the calcined limestone without $\mathrm{NaCl}$ doping, the mean pore size was about $0.07 \mu \mathrm{m}$. In order to elucidate in detail the effect of the $\mathrm{NaCl}$ doping on the $\mathrm{CaO}$ structure, crystal structures of the calcined seashell, the limestone and the $\mathrm{NaCl}$-doped limestone were analyzed by XRD. The spectra shown in Fig. 2 indicate that $\mathrm{CaO}$ in both the calcined seashell and the $\mathrm{NaCl}$-doped limestone is well crystallized, whereas the $\mathrm{CaO}$ in the calcined limestone is disordered. Therefore, this result suggests that $\mathrm{NaCl}$ doping can contribute to the crystallization of $\mathrm{CaO}$.

3.2 MD simulations on structures of $\mathrm{CaO}$ and $\mathrm{NaCl}-$ doped $\mathrm{CaO}$

The experimental results for the above-mentioned indicated that $\mathrm{NaCl}$ doping into the limestone can enlarge the pore size inside the $\mathrm{CaO}$ particles to enhance the $\mathrm{CaO}$ crystallization. To make clear the reason for this phenomenon, the change in $\mathrm{CaO}$ structures induced by the $\mathrm{NaCl}$ doping was calculated using the MD simulations. Figure 3 shows the changes of volume $(V)$, pressure $(P)$ and temperature $(T)$ for pure $\mathrm{CaO}$ and $\mathrm{NaCl}$-doped $\mathrm{CaO}$. The temperature of $6900 \mathrm{~K}$ corresponds to the minimum temperature for the formation of 


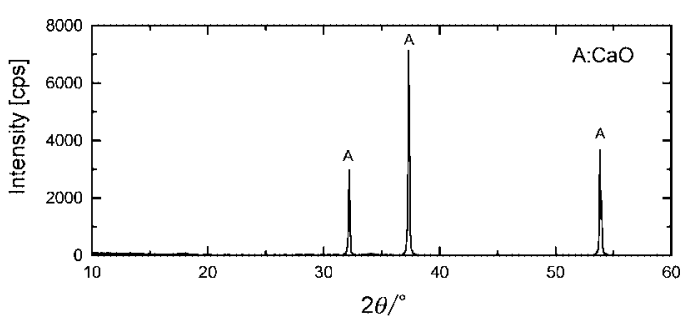

(a) Scallop

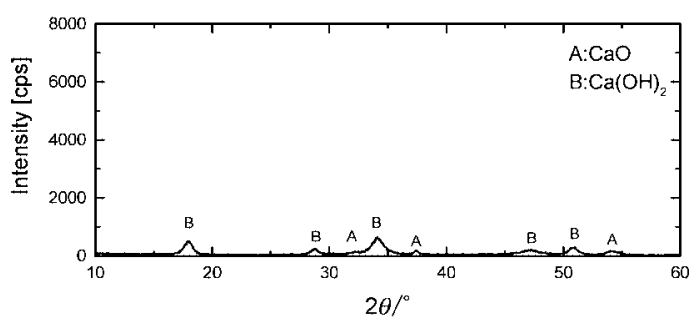

(b) Tsukumi limestone

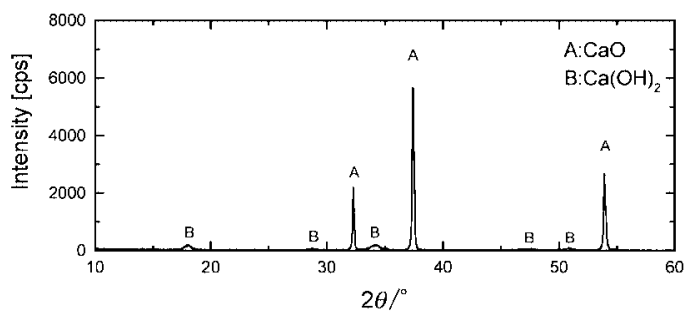

(c) Tsukumi limestone $+\mathrm{NaCl}(1 \mathrm{mass} \%)$

Fig. 2. XRD spectra of the calcined particles.

\section{1. pure $\mathrm{CaO}$ 2. $\mathrm{NaCl}$-doped $\mathrm{CaO}$}

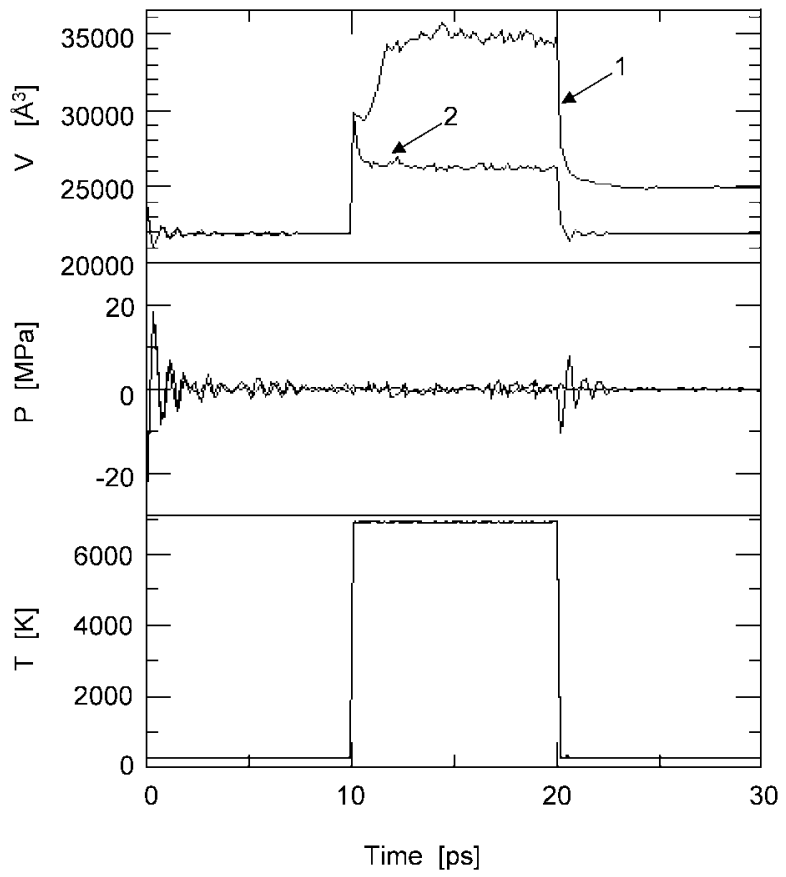

Fig. 3. Changes of volume $(V)$, pressure $(P)$ and temperature $(T)$ for (1) pure $\mathrm{CaO}$ and (2) $\mathrm{NaCl}$-doped $\mathrm{CaO}$.

the melted $\mathrm{CaO}$ structure in the present MD simulation using the Kawamura model. Although the simulated temperature is too high and not realistic, compared with the experimental melting temperature of the $\mathrm{CaO}$ species, the lattice constant of the $\mathrm{CaO}$ crystal could be simulated correctly, as shown in our previous study. ${ }^{14)}$ Additionally, the Kawamura model includes all parameters for $\mathrm{Ca}, \mathrm{O}, \mathrm{Na}, \mathrm{K}, \mathrm{Li}$ and $\mathrm{Cl}$ in the potential function shown in Eq. (1). Therefore, we adopted the potential function based on Kawamura's model and qualitatively discussed the change of the $\mathrm{CaO}$ structure induced by $\mathrm{NaCl}$ doping.

As shown in Fig. 3, the changes of volume and pressure at $298 \mathrm{~K}$ are quite small. The calculated mean bond length between $\mathrm{Ca}$ and $\mathrm{O}$ atoms is $2.30 \times 10^{-10} \mathrm{~m}\left(1 \times 10^{-10} \mathrm{~m}=1 \AA\right)$, which is a little shorter than the theoretical length of $2.41 \times$ $10^{-10} \mathrm{~m}^{11)}{ }^{12}$ At $6900 \mathrm{~K}(10-20 \mathrm{ps})$, the $\mathrm{CaO}$ structure is largely deformed due to the thermal vibrations of the $\mathrm{Ca}$ and $\mathrm{O}$ atoms, resulting in a volume expansion of 1.59 times as large as that of the initial $\mathrm{CaO}$ crystal structure at $298 \mathrm{~K}$. The structure at the high temperature is likely to be amorphous. By annealing this amorphous structure at $298 \mathrm{~K}$, the volume of $\mathrm{CaO}$ decreases rapidly. However, the volume of the annealed structure at $30 \mathrm{ps}$ is 1.13 times as large as that of the initial crystal structure. These results suggest that the amorphous $\mathrm{CaO}$ structure formed at $6900 \mathrm{~K}$ is too largely deformed to return to its initial crystal structure. Conversely, the $\mathrm{NaCl}-$ doped $\mathrm{CaO}$ can return to the initial crystal structure since the volume at $30 \mathrm{ps}$ is almost the same as that at $10 \mathrm{ps}$. This result indicates that the $\mathrm{NaCl}$ doping may affect the crystallization of the $\mathrm{CaO}$. During the early stage of the high temperature, the volume of $\mathrm{NaCl}$-doped $\mathrm{CaO}$ also expands to 1.35 times as large as that of the initial structure. However, the volume rapidly decreases after about 12 ps. After annealing, the volume is the same as that of the initial crystal structure at $298 \mathrm{~K}$. Consequently, the $\mathrm{NaCl}$-doped $\mathrm{CaO}$ seems to regain its initial crystal structure even after annealing. The temperature of $7100 \mathrm{~K}$ corresponds to the minimum temperature for the formation of melted $\mathrm{NaCl}$-doped $\mathrm{CaO}$ structure in this simulation.

To precisely illustrate the structural changes of pure $\mathrm{CaO}$ and $\mathrm{NaCl}$-doped $\mathrm{CaO}, 27$ atoms around the doped $\mathrm{NaCl}$ were picked out from the $\mathrm{CaO}$ structures. Figures $4(\mathrm{a})$ and (b) show the structures of pure $\mathrm{CaO}$ and $\mathrm{NaCl}$-doped $\mathrm{CaO}$ at 6900 $\mathrm{K}$, respectively. From Fig. 4(a), it is confirmed that the $\mathrm{CaO}$ molecules in pure $\mathrm{CaO}$ scatter randomly at $6900 \mathrm{~K}$. On the other hand, Fig. 4(b) shows the $\mathrm{NaCl}$-doped $\mathrm{CaO}$ maintains the crystal-like structure even at $6900 \mathrm{~K}$. Therefore, it is expected that the $\mathrm{NaCl}$ doping contributes to maintaining the crystal structure even at high temperatures. To elucidate the effect of $\mathrm{NaCl}$ doping on the crystallization, the change of the distances of the second nearest neighbor between the $\mathrm{Ca}$ and $\mathrm{O}$ atoms for pure $\mathrm{CaO}$ and $\mathrm{NaCl}$-doped $\mathrm{CaO}$ at $6900 \mathrm{~K}$ was investigated. In Figs. $5(\mathrm{a})$ and $(\mathrm{b}), \mathrm{Ca}-\mathrm{O}(m)$ highlights the distance between the $\mathrm{Ca}$ and $\mathrm{O}(\mathrm{m})$ atom shown in Fig. 4. The distances of the eight second nearest $\mathrm{Ca}-\mathrm{O}$ bonds are shown in these figures. Figure 5 (a) shows that all $\mathrm{Ca}-\mathrm{O}$ distances for pure $\mathrm{CaO}$ are equal before the temperature increases. As time advances, the distances of $\mathrm{Ca}-\mathrm{O}(1), \mathrm{Ca}-\mathrm{O}(6)$ and $\mathrm{Ca}-\mathrm{O}(8)$ increases suddenly, while the distance for $\mathrm{Ca}-\mathrm{O}(5)$ decreases. However, for the $\mathrm{NaCl}$-doped $\mathrm{CaO}$, the $\mathrm{Ca}-\mathrm{O}$ distances fluctuate largely at the early steps due to the $\mathrm{NaCl}$ doping, as shown in Fig. 5(b). Again, as time advances, the $\mathrm{Ca}-\mathrm{O}$ distances converge in the region between about 4 and $5 \times 10^{-10}$ $\mathrm{m}$. In other words, the structure of $\mathrm{NaCl}$-doped $\mathrm{CaO}$ transforms to an ordered structure even at $6900 \mathrm{~K}$.

In order to explain the reason for this behavior, the potential energies between the $\mathrm{Ca}$ atom and the nearest and the second nearest atoms for the pure $\mathrm{CaO}$ and $\mathrm{NaCl}$-doped $\mathrm{CaO}$ 

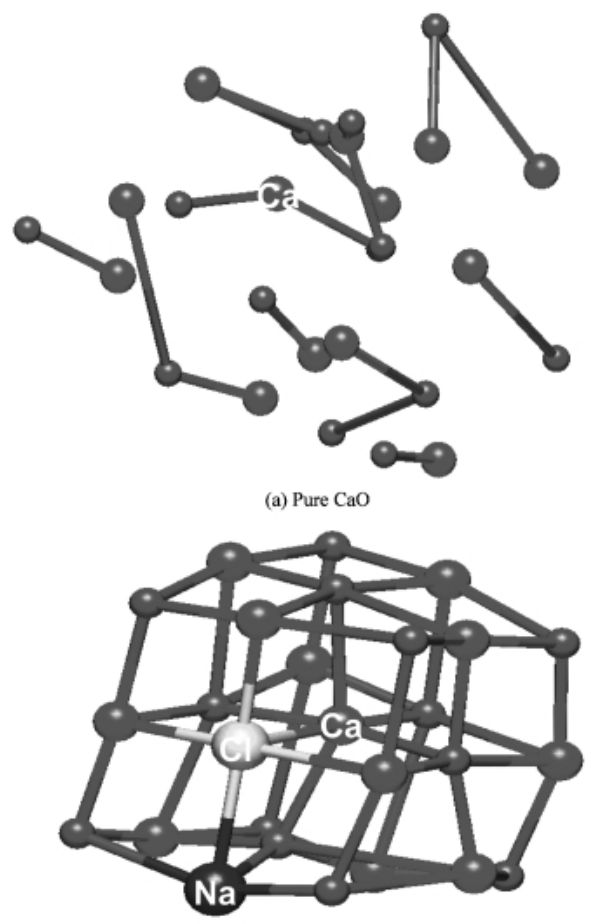

(b) $\mathrm{NaCl}$-doped $\mathrm{CaO}$

Fig. 4. (a) Positions of $\mathrm{Ca}$ and $\mathrm{O}$ atoms for pure $\mathrm{CaO}$ at $6900 \mathrm{~K}$ and (b) positions of $\mathrm{Ca}, \mathrm{O}, \mathrm{Na}$ and $\mathrm{Cl}$ atoms for $\mathrm{NaCl}$-doped $\mathrm{CaO}$ at $6900 \mathrm{~K}$.

are evaluated as shown in Table 2. Generally, more negative potential energy between the atoms means more stable bonding. Comparing the results for the pure $\mathrm{CaO}$ with that of the $\mathrm{NaCl}$-doped $\mathrm{CaO}$, both the potential energies of the nearest atoms and the second nearest atoms for the $\mathrm{NaCl}$-doped $\mathrm{CaO}$ is negatively larger than those of the pure $\mathrm{CaO}$. This is caused by the difference of atomic charges between the $\mathrm{Ca}$ and $\mathrm{Na}$ and/or between $\mathrm{O}$ and $\mathrm{Cl}$. In the $\mathrm{NaCl}$-doped $\mathrm{CaO}$, the $\mathrm{Ca}$ atom neighboring $\mathrm{Cl}$ has enough positive charge, since the $\mathrm{Ca}$ and $\mathrm{Cl}$ charge is +2 and -1 , respectively. Therefore, the potential energy of the second nearest $\mathrm{Ca}-\mathrm{O}$ in the $\mathrm{NaCl}-$ doped $\mathrm{CaO}$ becomes more negative than that in the pure $\mathrm{CaO}$, as shown in Table 2. This result means that the $\mathrm{Ca}$ atom in the $\mathrm{NaCl}$-doped $\mathrm{CaO}$ is more stable than that in the pure $\mathrm{CaO}$.

3.3 Comparison of the structures of $\mathrm{NaCl}, \mathrm{KCl}$ and $\mathrm{LiCl}$ doped to $\mathrm{CaOs}$

In the previous subsections of 3.1 and 3.2 , it was confirmed that $\mathrm{NaCl}$ was an effective additive to improve the desulfurization efficiency of limestone. Furthermore, the effect of other alkali chlorides of $\mathrm{KCl}$ and $\mathrm{LiCl}$ on the desulfurization efficiency was tested to elucidate whether those compounds have a similar function to $\mathrm{NaCl}$ or not.

The desulfurization experiments for $\mathrm{KCl}$ and LiCl-doped limestone were again conducted by using a thermobalance. As shown in Fig. 1, the desulfurization efficiency for the $\mathrm{KCl}$ doped limestone was much lower than that for the $\mathrm{NaCl}-$ doped limestone under the condition of a low addition fraction. The desulfurization efficiency became approximately $30 \%$ when 1 mass $\%$ of $\mathrm{KCl}$ was added into the limestone. As for the $\mathrm{LiCl}$ addition into the limestone, the desulfurization efficiency became about only $23 \%$ when 1 mass $\%$ of the $\mathrm{LiCl}$ was added into the limestone. From the results for $\mathrm{KCl}$ and $\mathrm{LiCl}$ dopings, it is concluded that the effect of these compounds on the desulfurization is much smaller than that of
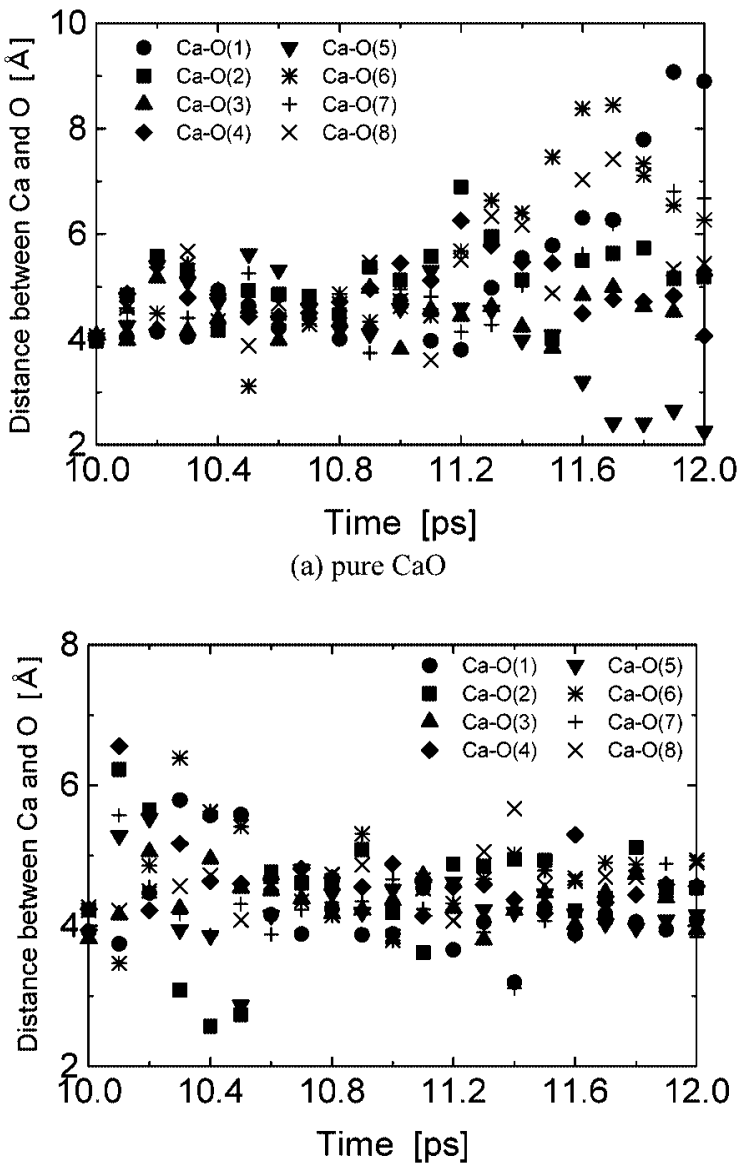

(b) $\mathrm{NaCl}$-doped $\mathrm{CaO}$

Fig. 5. Changes of distances between $\mathrm{Ca}$ and the second nearest $\mathrm{O}$ atoms at $6900 \mathrm{~K}$ for (a) pure $\mathrm{CaO}$ and (b) $\mathrm{NaCl}$-doped $\mathrm{CaO}$.

Table 2. Interaction Energies between the $\mathrm{Ca}$ Atom and the Nearest and the Second Nearest Atoms for the Pure $\mathrm{CaO}$ and $\mathrm{NaCl}-\mathrm{Doped}$ $\mathrm{CaO}$

\begin{tabular}{ccccc}
\hline & \multicolumn{4}{c}{ Potential energy $[\mathrm{eV}]$} \\
\cline { 2 - 5 } & $\begin{array}{c}\mathrm{Ca}-\mathrm{O} 6 \\
\text { Pure } \mathrm{CaO}\end{array}$ & $\begin{array}{c}\mathrm{Ca}-\mathrm{Ox} 8 \\
\text { (the nearest } \\
\text { (the second }\end{array}$ & $\begin{array}{c}\mathrm{Ca}-\mathrm{Cl}+\mathrm{Ca}-\mathrm{O} \times 5 \\
\text { (the nearest }\end{array}$ & $\begin{array}{c}\mathrm{Ca}-\mathrm{O} 8 \\
\text { (the second }\end{array}$ \\
atoms) & nearest atoms) & atoms) & nearest atoms) \\
\hline $6900 \mathrm{~K}$ & $-\mathbf{1 2 3 . 1 1}$ & -94.18 & -128.61 & -103.60 \\
\hline
\end{tabular}

$\mathrm{NaCl}$.

The MD simulations were also performed for the $\mathrm{KCl}$ and $\mathrm{LiCl}$-doped to $\mathrm{CaO}$ to understand the effect of these doping on the $\mathrm{CaO}$ structure. Figures $6(\mathrm{a})$, (b) and (c) show the structures of the $\mathrm{NaCl}$-doped $\mathrm{CaO}$, the $\mathrm{KCl}$-doped $\mathrm{CaO}$ and the $\mathrm{LiCl}$-doped $\mathrm{CaO}$ at $7000 \mathrm{~K}$, respectively. At this temperature, the crystal structure was kept in all conditions. In the $\mathrm{KCl}$-doped $\mathrm{CaO}$, the $\mathrm{K}$ and the $\mathrm{Cl}$ atoms are further apart from each other, as shown in Fig. 6(b). This means that the interaction energy between the $\mathrm{K}$ and the $\mathrm{Cl}$ atoms is weaker than that between the $\mathrm{Na}$ and the $\mathrm{Cl}$ atoms. As a result, the structure around the $\mathrm{Cl}$ atom is more deformed from the crystal structure than Fig. 6(a) for the $\mathrm{NaCl}$-doped $\mathrm{CaO}$. In the $\mathrm{LiCl}$-doped $\mathrm{CaO}$ at high temperature, the $\mathrm{Li}$ can move freely inside the $\mathrm{CaO}$ crystal lattice, as shown in Fig. 6(c). This result may be due to the small ion radius $\left(0.90 \times 10^{-10} \mathrm{~m}\right)$ of the $\mathrm{Li}$, compared with that $\left(1.16 \times 10^{-10} \mathrm{~m}\right)$ for the $\mathrm{Na}$. Therefore, it is not expected that the $\mathrm{LiCl}$ doping into lime- 


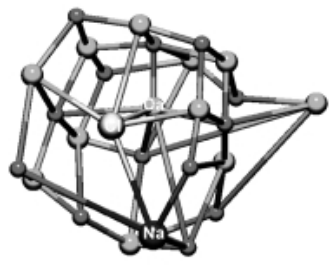

(a) $\mathrm{NaCl}$-doped $\mathrm{CaO}$

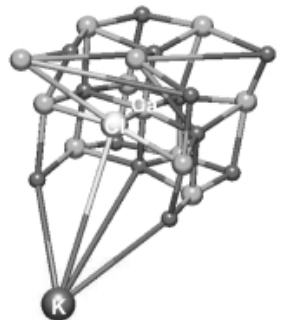

(b) $\mathrm{KCl}$-doped $\mathrm{CaO}$

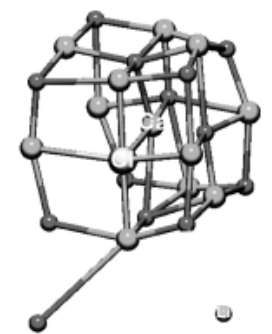

(c) LiCl-doped $\mathrm{CaO}$

Fig. 6. (a) Positions of $\mathrm{Ca}, \mathrm{O}, \mathrm{Na}$ and $\mathrm{Cl}$ atoms for $\mathrm{NaCl}$-doped $\mathrm{CaO}$, (b) Positions of $\mathrm{Ca}, \mathrm{O}, \mathrm{K}$ and $\mathrm{Cl}$ atoms for $\mathrm{KCl}$-doped $\mathrm{CaO}$ and (c) Positions of $\mathrm{Ca}, \mathrm{O}, \mathrm{Li}$ and $\mathrm{Cl}$ atoms for $\mathrm{LiCl}$-doped $\mathrm{CaO}$ at $7000 \mathrm{~K}$.

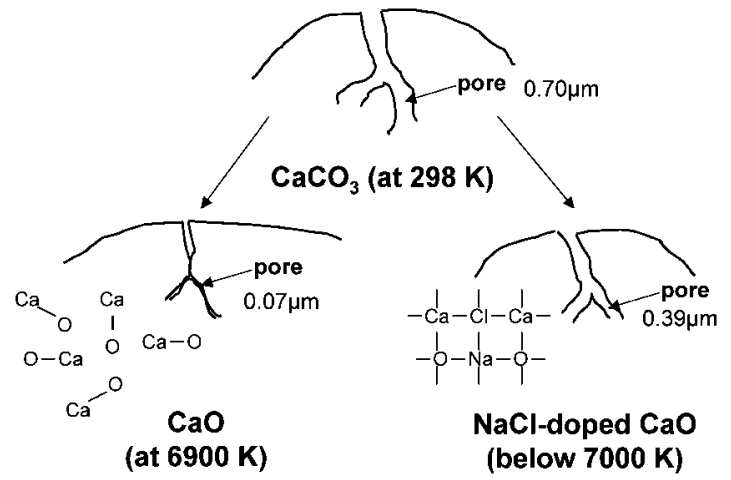

Fig. 7. Schematic picture showing the change in the pore size of pure $\mathrm{CaO}$ and $\mathrm{NaCl}$-doped $\mathrm{CaO}$.

stone can contribute to the $\mathrm{CaO}$ crystallization.

From the experimental and MD studies, it is confirmed that the $\mathrm{NaCl}$ doping into the limestone is more effective to enhance the desulfurization efficiency than those of $\mathrm{KCl}$ and $\mathrm{LiCl}$. Among the $\mathrm{Na}, \mathrm{K}$ and $\mathrm{Li}$ ions, $\mathrm{Na}$ is found to be the most appropriate for the substitute of $\mathrm{Ca}$ in a $\mathrm{CaO}$ crystal because the ion radius of $\mathrm{Na}$ is similar to that of $\mathrm{Ca}(1.14 \times$ $10^{-10} \mathrm{~m}$ ). Figure 7 is a schematic picture showing the change of the $\mathrm{CaO}$ structure. The mean pore size of the calcined $\mathrm{NaCl}$-doped $\mathrm{CaO}$ was over six times as large as that of the calcined pure $\mathrm{CaO}$. This result can be attributed from the fact that $\mathrm{NaCl}$-doped $\mathrm{CaO}$ can retain the crystal structure at the calcination temperature. As a result, the desulfurization reaction can be produced over the whole of a particle for the $\mathrm{NaCl}$ doped $\mathrm{CaO}$, so that the desulfurization efficiency of the $\mathrm{NaCl}$ doped $\mathrm{CaO}$ is higher than that of the pure $\mathrm{CaO}$.

\section{Conclusions}

The effect of the doping of alkali metal compounds $(\mathrm{NaCl}$, $\mathrm{KCl}$ and $\mathrm{LiCl}$ ) into limestone on the desulfurization charac- teristics was studied by both experiments and MD simulations. The desulfurization experiments showed that the pore size of the calcined $\mathrm{NaCl}$-doped limestone was almost the same as that of the calcined seashell and much larger than that of the calcined limestone without the $\mathrm{NaCl}$ addition. The XRD analysis indicated the $\mathrm{CaO}$ in both seashell and the $\mathrm{NaCl}$-doped limestone was crystallized, whereas $\mathrm{CaO}$ in the calcined limestone was in a disordered form. The desulfurization efficiency of limestone was enhanced largely by the $\mathrm{NaCl}$ addition when compared to the $\mathrm{KCl}$ and $\mathrm{LiCl}$ additions.

The change of structure of the $\mathrm{CaO}$ induced by the $\mathrm{NaCl}$, $\mathrm{KCl}$ and $\mathrm{LiCl}$ substitutions was calculated by the MD simulations based on the potential parameters developed by Kawamura. The results indicated that the addition of $\mathrm{NaCl}$ into the limestone was the most effective for improving the $\mathrm{CaO}$ crystallization. The structure of the $\mathrm{NaCl}$-doped $\mathrm{CaO}$ was stable even at high temperatures, while the pure $\mathrm{CaO}$ was unstable at the same temperature. On the other hand, the $\mathrm{KCl}$ and $\mathrm{LiCl}$ dopings into the $\mathrm{CaO}$ had a smaller effect on the $\mathrm{CaO}$ crystallization than the $\mathrm{NaCl}$ doping. Consequently, from the results of the experiments and the MD simulations, it can be concluded that the $\mathrm{NaCl}$ doping into the limestone was the most effective for improving the desulfurization efficiency.

\section{Notation}

$A$ : potential parameter

$B$ : potential parameter

$C$ : potential parameter

$D:$ potential parameter

$E$ : potential energy

$e:$ electron

$g:$ pair correlation functions

$i$ : number of atom

$j$ : number of atom

$r$ : interatomic distance

$Z$ : charge

\section{References}

1) Leckner, B. and Amand, L. E., Am. Soc. Mech. Eng., pp. 891-897 (1987).

2) Zhang, J. Q., Jones, W. E., Lau, I. T. and Friedrich, F. D., Am. Soc. Mech. Eng., pp. 639-648 (1991).

3) Hartman, M. and Coughlin, R. W., Ind. Eng. Chem., Process Des. Develop., Vol. 13, pp. 248-253 (1974).

4) Naruse, I., Nishimura, K., Ohtake, K. and Kawabe, T., Kagaku Kogaku Ronbunshu, Vol. 21, pp. 904-909 (1995) [in Japanese].

5) Murakami, T., Saito, K. and Naruse, I., J. of Japan Inst. of Energy, Vol. 79, pp. 1070-1077 (2000) [in Japanese].

6) Bulewicz, E. M. and Janicka, E., J. of Inst. of Energy, Vol. 9, pp. 124-130 (1990).

7) Davini, P., DeMichele, G. and Ghetti, P., Fuel, Vol. 71, pp. 831-834 (1992).

8) Shearer, J. A., Johnson, I. and Turner, C. B., Env. Sci. \& Tech., Vol. 13, pp. 1113-1118 (1979).

9) Smith, G. W., Lenc, J. F., Shearer, J. A., Chopra, O. K., Myles, K. M. and Johnson, I., Annual Report, Argone., Vol. 7, pp. 1-31 (1981).

10) Fujitsu Co. Ltd., WinMASPHYC Pro 1.0 User's Guide (2000) [in Japanese].

11) Hirao, K. and Kawamura, K., "Pasokon ni yoru Zairyou Sekkei," Shoukabo (1994) pp. 44-70 [in Japanese].

12) Wyckoff, R. W. G., “Crystal Structures,” Vol. 1, John Wiley \& Sons (1963) pp. 85-94.

13) Yamahara, K., Okazaki, K. and Kawamura, K., J. Non-Cryst. Solids, Vol. 291, pp. 32-42 (2001).

14) Murakami, T., Kurita, N. and Naruse, I., J. of Chem. Eng. of Japan, Vol. 36, pp. 225-230 (2003). 